Jurnal IImu Komunikasi UHO : Jurnal Penelitian Kajian Ilmu Komunikasi dan Informasi.

Volume 6, No. 4, Oktober 2021, hlm 501-515

\title{
PERSEPSI KOMUNITAS SHOPEE TANAM PADA BRAND AMBASSADOR KPOP STRAY KIDS
}

\author{
Sena Luktridiansyah Pawelloi ${ }^{1}$ Muh. Aswan Zanynu ${ }^{2}$ Marsia Sumule $^{3}$ \\ Jurusan Ilmu Komunikasi \\ Fakultas Ilmu Sosial dan Ilmu Politik \\ Universitas Halu Oleo \\ Kendari-Sulawesi Tenggara \\ senaluktri93@gmail.com
}

\begin{abstract}
ABSTRAK
Tujuan penelitian ini adalah untuk mengetahui Persepsi Komunitas Shopee Tanam pada Brand Ambassdor Stray Kids. Penelitian ini dilaksanakan pada Komunitas Shopee Tanam. Informan dalam penelitian ini sebanyak tujuh orang yang ditentukan menggunakan purposive sampling yakni sampel bertujuan dengan pertimbangan dapat memberikan informasi yang diperlukan untuk penelitian. Jenis data dalam penelitian ini adalah data kualitatif dengan sumber data berupa data primer dan data sekunder. Teknik pengumpulan data dilakukan dengan cara studi pustaka, wawancara, dan dokumentasi. Teknik analisis data mencakup pendeskripsian hasil temuan penelitian, yang selanjutnya diberi penafsiran dan kesimpulan. Hasil penelitian ini menunjukan bahwa persepsi Komunitas Shopee Tanam pada brand ambassador Stray Kids menghasilkan persepsi yang baik dan positif. Terdapat beberapa faktor yang mempengaruhi persepsi yakni, pesan mudah tersampaikan, trend Korea di Indonesia, kepopuleran stray kids, daya tarik fisik dan non fisik Stray Kids. Analisis dalam penelitian ini menunjukkan bahwa penilaian pada brand ambassador Stray Kids dipengaruhi akibat populer culture (trend Korea) karena berada pada Assimilation (rentang penerimaan persepsi) yang terjadi akibat Selective Attention (Perhatian Selektif), Selective Distorsion (Distorsi Selektif), dan Selective Retention (Ingatan Selektif).
\end{abstract}

Kata Kunci: Persepsi, Komunitas Shopee Tanam, Brand Ambassador, Stray Kids 
Jurnal IImu Komunikasi UHO : Jurnal Penelitian Kajian IImu Komunikasi dan Informasi.

Volume 6, No. 4, Oktober 2021, hlm 501-515

\title{
SHOPEE COMMUNITY TANAM PERCEPTION ON KPOP BRAND AMBASSADOR STRAY KIDS
}

\begin{abstract}
This research aims to find out the Perception of Shopee Tanam Community on Stray Kids Brand Ambassador. Informants in this study as many as seven people determined using purposive sampling that is a sample aim with consideration can provide the necessary information for research. The data type in this study is qualitative data with data sources in primary and secondary data. Data collection techniques are performed through library studies, interviews, and documentation. Data analysis techniques include decryption of research findings, which are then given interpretations and conclusions. This study showed that the perception of Shopee Tanam Community in Stray Kids brand ambassadors produced good and positive perceptions. Several factors influence perception: the message is easily conveyed, the Korean trend in Indonesia, the popularity of stray kids, and the physical and non-physical attractiveness of Stray Kids. The analysis in this study showed that the assessment of Stray Kids brand ambassadors was influenced by popular culture (Korean trend) because it was in Assimilation (range of perception acceptance) that occurred due to Selective Attention, Selective Distortion, and Selective Retention.
\end{abstract}

Keywords: Perception, Shopee Tanam Community, Brand Ambassador, Stray Kids. 
Jurnal Ilmu Komunikasi UHO : Jurnal Penelitian Kajian IImu Komunikasi dan Informasi.

Volume 6, No. 4, Oktober 2021, hlm 501-515

\section{PENDAHULUAN}

Internet memberi kemudahan untuk mengakses, mencari, dan menemukan informasi. Kehadiran internet tidak hanya membawa perubahan pada perkembangan teknologi saja, akan tetapi membawa perubahan terhadap kehidupan masyarakat. Pengaruh ke dalam berbagai aspek kehidupan masyarakat bisa dipengaruhi oleh internet, seperti misalnya pengaruh terhadap pendidikan, ekonomi, kehidupan sosial bahkan budaya dalam masyarakat.

Survey yang di lakukan oleh Hootsuite pada tahun 2021 pengguna internet mencapai 200 juta jiwa dari total 270 juta penduduk Indonesia menggunakan internet, terlihat jelas bahwa penggunaan internet di Indonesia mencapai angka yang sangat tinggi hal ini dapat ditinjau dengan aktifnya pengguna internet. Dengan potensi jumlah pengguna internet di Indonesia yang sangat pesat membawa peluang inovasi dari wirausahawan dengan memanfaatkan E-Commerce untuk meningkatkan penjualan.

E-Commerce atau singkatan dari Electronic Commerce (perdagangan secara electronik), merupakan transaksi bisnis yang terjadi dalam jaringan elektronik, seperti internet. Siapa pun yang dapat mengakses komputer, memiliki sambungan ke internet, dan memiliki cara untuk membayar barang-barang atau jasa yang mereka beli dapat berpartisipasi dalam E-Commerce Shely (dalam Ummah, 2018: 14). E-Commerce atau pasar yang berbasis daring identik dengan sarana transaksi jual beli yang dilakukan secara online melalui website dan aplikasi $E$ Commerce. Kecanggihan perdangangan E-Commerce membuat pengguna dipermudah dalam transaksi jual beli yang tidak mengenal batasan ruang dan waktu. Sekali klik barang yang diinginkan dapat diperoleh dengan mudah.

Shopee merupakan E-Commerce yang telah berdiri sejak tahun 2015 dan didirikan oleh Chris Feng. Perkembangan Shopee diawali pada tahun 2015 di negara Singapura dan memperluas jangkauannya keberbagai negara yakni; Indonesia, Malaysia, Thailand, Taiwan, Vietnam, Filipina, Brazil dan beberapa negara lainnya. Perkembangan dan popularitas Shopee dapat dilihat dari hasil survey yang dilakukan oleh Snapchart, snapchart merupakan aplikasi mobile yang menawarkan cashback kepada pengguna dengan syarat untuk mengunggah struk belanja dan mengisi survey, adapun hasil survey Snapchart dalam duniafintech.com pada tahun 2020 bahwa Shopee menduduki urutan pertama dengan jumlah 49\%, lalu pada urutan kedua yaitu goyang shopee dengan jumlah 10\% dan seterusnya disusul oleh fitur games E-Commerce ISSN: 2527-9173. Website: http://ojs.uho.ac.id/index.php/KOMUNIKASI/index 
Jurnal IImu Komunikasi UHO : Jurnal Penelitian Kajian Ilmu Komunikasi dan Informasi.

Volume 6, No. 4, Oktober 2021, hlm 501-515

lainnya. Shopee berada pada urutan pertama disebabkan adanya komunitas fitur tanam. Snapchart juga melakukan riset berdasarkan kelompok usia, dikutip oleh Duniafintech.com bahwa berbelanja diShopee paling disukai oleh kelompok usia 17-24 tahun dengan jumlah (72\%), usia 25-30 tahun dengan jumlah (69\%), dan usia diatas 35 tahun berjumlah dibawah (55\%), menurut direktur snapchart Astrid Wiliandry "Shopee menjadi utama dikalangan usia tertentu karena adanya fitur-fitur di Shopee yang interaktif dan memiliki daya tarik tersendiri”.

Fitur Shopee tanam merupakan fitur atau game dimana permainan ini menuntut para pemain untuk menanam tanaman dengan tujuan untuk mendapatkan koin yang dapat ditukar menjadi voucher potongan harga dan event lainnya. Game ini menugaskan para pemain untuk mendapat bantuan dari teman-teman yang telah membantu atau menyiram tanaman mereka dengan cara mengklik link yang telah dibagikan, semakin berkembang tanaman tersebut semakin mendapatkan keuntungan koin yang lebih besar (panen). Dengan adanya fitur tersebut menghadirkan berbagai perkembangan salah satunya yaitu komunitas atau grup online Shopee tanam, Komunitas ini merupakan suatu komunitas yang berada dalam sebuah aplikasi chatting Whatsapp dengan jumlah anggota saat ini tanggal (5 Maret 2021) yaitu 158 orang jumlah ini dapat berubah sewaktu - waktu. Komunitas ini merupakan tempat dimana pengguna Shopee dapat membagikan link games yang bertujuan untuk mendapat bantuan dari anggota komunitas lainnya dengan menelusuri link tersebut.

Akibat pesatnya perkembangan E-Commerce di era digital saat ini menuntut pelaku usaha untuk dapat bersaing dalam membangun nama merek kepada khalayak demi keberlangsungan suatu perusahaan. Salah satu strategi yang sering dijumpai oleh khakayak yaitu penggunaan brand ambassador Menurut Royan (dalam, Prawira et al., 2012) brand ambassador ialah seseorang yang dipercaya untuk mewakili produk tertentu dan bertujuan untuk dapat mempengaruhi atau mengajak konsumen untuk menggunakan sebuah produk. Shopee merupakan E-Commerce yang menggunakan brand ambassador sebagai bentuk promosi brand mereka.

Untuk memperkuat mengenai persepsi konsumen pada brand ambassador peneliti menemukan pro-kontra yang terjadi di ruang publik khususnya di era digital saat ini, beragam respon atau persepsi yang diungkapkan melalui berbagai media sosial pada brand ambassador 
Jurnal IImu Komunikasi UHO : Jurnal Penelitian Kajian Ilmu Komunikasi dan Informasi.

Volume 6, No. 4, Oktober 2021, hlm 501-515

salah satu E-Commerce Shopee yaitu Blackpink dan Christiano Ronaldo yang kehadiran mereka seharusnya memberikan citra yang baik atau positif tetapi menimbulkan persepsi yang prokontra. Dilansir oleh Kumparan.com (tanggal, 11 Desember 2018) komentar akun twitter @ handokotjung “iklan BlackPink pake celana pendek: Ban! Merusak akhlak!” lalu terdapat berita berisikan petisi "Hentikan Iklan Blackpink Shopee" yang dibuat oleh Maimon Herawati dilansir oleh change.org dan tak hanya pada kasus blackpink saja tetapi pada penggunaan brand ambassador Ronaldo juga banyak menuai respon positif dan negatif yakni, komentar positif oleh akun Rahmat Dayat "Pada intinya cr7 pribadi yang rendah hati, ramah ramah jadi jangan respon yang aneh2", oleh akun Ahmad Fahried "Ronaldo Pemain bola Ganteng Idola banyak orang 2019 Goyang Shopee" dan ada juga respon publik yang negative yakni, oleh akun Iltizam Muwafiq "Ronaldo menjadi pesepakbola karismatik selama 15 tahun dan shopee merusaknya dalam 30 detik". Oleh karena itu pemilihan dan penggunaan brand ambassador memiliki peran penting terhadap persepsi konsumen, peneliti melakukan penelitian guna melihat bagaimana persepsi konsumen Shopee atau Komunitas Shopee Tanam pada brand ambassador Shopee terbaru 2021 yaitu Stray Kids dengan memfokuskan pada karakteristik brand ambassador menurut Lea-Greenwood, (2013) yaitu, transference (Tersampaikan), Attractiveness (Daya Tarik), dan Congruence (Kesesuaian)

Berbagai persepsi dan penilaian di ruang publik terkait brand ambassador banyak menghadirkan berbagai respon, hal ini dapat dilihat bahwa kehadiran brand ambassador tersebut tidak semua diterima oleh publik dan bahkan mengakibatkan citra brand yang diharapkan dapat meningkat tetapi menjadi sebaliknya, Shopee pada tahun 2021 menggunakan jasa Kpop brand ambassador Stray Kids dan menjadi fokus penelitian ini. Dari fenomena di atas menghadirkan berbagai penilaian sosial dengan bermacam-macam sudut pandang mengenai brand ambassador dan penulis menggunakan Teori Penilaian Sosial Sherif 1961(dalam Morissan, 2013) yang menjelaskan tentang cara seseorang membuat penilaian mengenai pernyataan atau informasi yang diterimanya, terdapat asumsi dalam teori ini yakni, Contrast (Rentang Penolakan), Rentang Non Comitment (Netral), Assimilation (Rentang Penerimaan). 
Jurnal IImu Komunikasi UHO : Jurnal Penelitian Kajian IImu Komunikasi dan Informasi.

Volume 6, No. 4, Oktober 2021, hIm 501-515

\section{METODE PENELITIAN}

Penelitian ini akan dilaksanakan pada Komunitas Tanam Shopee yang berada pada aplikasi chatting Whatsapp dengan menggunakan metode kualitatif. Alasan mengapa penulis memilih lokasi penelitian tersebut dikarenakan penulis ingin mengetahui bagaimana persepsi konsumen Shopee atau anggota komunitas Shopee tanam mengenai brand ambassador Shopee Stray Kids dan juga atas pertimbangan bahwa komunitas ini berada dalam sistem online. Subjek dalam penelitian ini adalah anggota Komunitas Shopee Tanam yang merupakan konsumen dan mengikuti perkembangan Shopee. Berdasarkan subjek penelitian yang ada, peneliti menentukan informan menggunakan purposive sampling dengan jumlah sebanyak 7 orang yang memenuhi karkateristik penentuan informan yakni; merupakan konsumen aktif Shopee, pernah diterpa atau melihat iklan brand ambassador Shopee Stray Kids, mengetahui setidaknya dua brand ambassador Shopee, dan rentang usia 17 tahun sampai 35 tahun. Penentuan informan dianggap telah memadai apabila informasi telah jenuh dan tidak memberi informasi baru. Data-data kualitatif baik primer maupun sekunder diperoleh dengan menggunakan studi kepustakaan, wawancara dan dokumentasi. Selanjutnya data tersebut dianalisis dan dirangkum menjadi informasi yang dapat memperoleh kesimpulan. Penarikan simpulan kemudian dilakukan berdasarkan hasil analisis terhadap hasil wawancara dan studi kepustakan.

\section{HASIL PENELITIAN DAN PEMBAHASAN}

\section{Persepsi Komunitas Shopee Tanam pada Brand Ambassador Stray Kids}

Persepsi konsumen merupakan proses dimana terbentuknya makna mengenai produk atau brand yang diakibatkan karena diterimanya stimulus dengan melalui langkah-langkah seperti penerimaan pesan, makna isi pesan, dan penafsiran akhir pesan sehingga terbentuknya persepsi konsumen. Menurut Kotler \& Keller, (2009) persepsi konsumen merupakan proses dimana individu dalam memilih, mengatur, dan menerjemahkan informasi yang masuk untuk menciptakan gambaran bermakna.

Hasil penelitian menunjukkan bahwa persepsi anggota Komunitas Shopee Tanam pada brand ambassador Stray Kids memberikan tanggapan yang positif, ketujuh informan mengungkapkan beberapa faktor yang mempengaruhi pendapat mereka mengenai Stray Kids yakni, Kepopuleran, Pengalaman Membintangi Brand Lain, Trend Kpop Di Indonesia, ISSN: 2527-9173. Website: http://ojs.uho.ac.id/index.php/KOMUNIKASI/index 
Jurnal Ilmu Komunikasi UHO : Jurnal Penelitian Kajian IImu Komunikasi dan Informasi.

Volume 6, No. 4, Oktober 2021, hlm 501-515

Kesesuaian karakter, dan Daya tarik fisik (Seperti Ketampanan, Fashion, dan Postur Tubuh), Non-Fisik seperti (Pengalaman, Latar belakang, Tampilan Visual gambar dan suara). Dari tanggapan ketujuh informan terjadi beberapa proses pembentukan dan penilaian persepsi yakni, Efek Contrast, Assimilation, Latitude of noncommitment Sherif (dalam Morissan, 2013: 79). Guna memaparkan proses terbentuknya penilaian dan persepsi anggota Komunitas Shopee Tanam pada brand ambassador Stray Kids, berikut penjabaran hasil dan pembahasan penelitian.

\section{Efek Assimilation (Penerimaan Persepsi)}

Efek assimilation merupakan indikator dimana persepsi tersebut telah berada dalam kondisi penerimaan, hal ini termasuk kedalam rentang penerimaan (latitude of acceptance), penilaian tersebut tergantung dari pemikiran mereka terhadap suatu objek. Dari total ketujuh informan enam diantaranya menilai brand ambassador Stray Kids menunjukkan hasil yang positif. Keenam informan menilai bahwa Stray Kids sangat bagus dan cocok untuk membintangi iklan E-Commerce Shopee, informan Dhio Alghifary, Yana Adnanir dan Emilia Zahra mengatakan bahwa salah satu faktor pendukung Stray Kids adalah kepopuleran mereka sebagai Kpop. Selain kepopuleran menurut informan Diva Yoti Agustian dan La Ode Abu Bakar Ramli Stray Kids memiliki daya tarik fisik yang membuat penonton senang melihatnya dan wajah yang ganteng-ganteng menjadi faktor pendukung menurut mereka.

Menurut informan yang bernama Puradian Wiryadigda bahwa stray kids mewakili bagian atau kalangan milenial saat ini, menurutnya iklan shopee memiliki segment atau target pasar yang beragam, untuk Stray Kids mewakili kalangan penggemar Kpop di Indonesia. Jawaban serupa juga katakan oleh La Ode Abu bakar Ramli bahwa trend Kpop di Indonesia sangat populer saat ini sehingga shopee berani menggunakan jasa Stray Kids. Hal lain dikatakan oleh Informan bernama Emilia Zahra yang menambahkan pendapatnya bahwa iklan Shopee Stray Kids menggunakan nada salah satu lagu populer Stray Kids berjudul "God's Menu" sehingga menjadi keunikan tersendiri.

Untuk melihat bagaimana kesuksesan brand ambassador Stray Kids peneliti menganalisa pendapat yang diutarakan ketiga informan yang bernama Diva Yoti Agustian, Yana Adnanir dan Dhio Alghifary menurut mereka brand ambassador Stray kids memiliki kesuksesan tersendiri, mereka menilai dari jumlah tayangan iklan Stray Kids yang mencapai angka ratusan ribu, menurut informan Puradian Wiryadigda kesuksesan tersebut dihasilkan dari makna pesan iklan 
Jurnal IImu Komunikasi UHO : Jurnal Penelitian Kajian IImu Komunikasi dan Informasi.

Volume 6, No. 4, Oktober 2021, hlm 501-515

tersebut, penggunaan bahasa Indonesia dalam pesan promosi menjadi kunci kesuksesan Stray Kids sebagai brand ambassador. Hal serupa juga dikatakan oleh La Ode Abu Bakar Ramli dan Emilia Zahra bahwa kesuksesan brand ambassador Stray Kids tidak hanya dari jumlah tayangan saja akan tetapi respon like serta komentar dalam kolom komentar yang berisi positif-positif, hal ini menurut La Ode Abu Bakar Ramli karena antusias penggemar kpop di Indonesia yang banyak.

Penilaian keenam informan masuk kedalam efek assimilation yaitu penerimaan dikarenakan pendapat mereka berdasarkan pengalaman dan pengetahuan mereka terkait brand ambassador Stray Kids yang telah mereka ketahui sebelumnya, hal ini yang menjadi penguat bahwa keenam informan berada pada efek assimilation atau rentang penerimaan.

\section{Contrast (Penolakan Persepsi)}

Efek contrast merupakan indikator dimana persepsi tersebut telah berada dalam kondisi penolakan, hal ini termasuk kedalam rentang rentang penolakan (latitude of rejection), penilaian tersebut tergantung pada pemikiran mereka terhadap objek. Dari hasil wawancara ketujuh informan bahwa menunjukkan penilaian atau persepsi positif dan baik, sehingga efek contrast (penolakan) dalam penelitan ini tidak terjadi.

\section{Rentang Tidak Komitmen (latitude of noncommitment)}

Rentang tidak komitmen ini merupakan situasi dimana pesan yang diterima berada antara wilayah penerimaan dan wilayah netral, dalam wilayah ini kemungkinan terjadinya perubahan sikap yang dipertimbangkan karena berada diantara wilayah penerimaan dan wilayah netral, terkecuali persepsi tersebut berada pada wilayah penolakan maka perubahan sikap dan penilaian individu tidak akan terjadi.

Hal ini terjadi pada penilaian informan yang bernama Ahmad Zulfadli menurutnya brand ambassador Stray Kids kurang cocok membintangi iklan Shopee, hal ini disebabkan karena adanya ketidaksesuaian antara E-Commerce dan idol Kpop, seperti diketahui E-Commerce Shopee menjual berbagai barang dan produk dan hal tersebut menurutnya tidak memiliki hubungan dengan Stray Kids, Ahmad Zulfadli menilai bahwa Shopee lebih cocoknya menggunakan jasa entrepreneur yang lebih mendunia dan lebih dikenal banyak kalangan, selain itu Ahmad Zulfadli menambahkan pendapatnya bahwa Stray Kids memang terkenal di bagian Asia saja sehingga informan menyarankan untuk menggunakan entrepreneur yang lebih 
Jurnal IImu Komunikasi UHO : Jurnal Penelitian Kajian Ilmu Komunikasi dan Informasi.

Volume 6, No. 4, Oktober 2021, hlm 501-515

mendunia. Informan Ahmad Zulfadli juga menilai kesuksesan Stray Kids menurutnya lumayan sukses karena menurutnya fans Kpop di Indonesia saat ini sangat banyak, jumlah tayang iklan juga lumayan dan Ahmad Zulfadli juga menambahkan bahwa mungkin target pasar shopee untuk iklan tersebut adalah penggemar Kpop.

Hal ini menunjukkan bahwa persepsi atau pendapat informan Ahmad Zulfadli dipengaruhi akibat Selective Retention menurut Kotler \& Keller (2009)) bahwa hal ini terjadi pada saat seseorang hanya mengingat informasi yang mendukung perasaan dan kepercayaannya. Peristiwa ini terjadi pada informan yang bernama Ahmad Zulfadli karena menurutnya Shopee lebih memiliki kesesuaian bersama entrepreneur yang mendunia dari pada Stray Kids yang terkenal di bagian Asia saja. Tetapi menurutnya brand ambassador Stray kids menunjukkan kesuksesan yang "lumayan" karena melihat jumlah tayangan iklan dan trend Kpop di Indonesia. Terkait dengan Selective Retention atau ingatan selektif bahwa informan Ahmad Zulfadli memiliki pengalaman, pengetahuan, dan mengingat kembali mengenai ketenaran Stray Kids di bagian Asia, sehingga menurutnya Shopee lebih memiliki kesesuaian jika menggunakan brand ambassador yang lebih mendunia dan banyak dikenal berbagai kalangan.

Penilaian informan Ahmad Zulfadli mengenai Stray Kids ini dipertimbangkan karena berbagai hal, penggunaan kata "lumayan sukses" dan "kurang cocok" memberi bukti bahwa pendapat informan tersebut berada pada rentang tidak komitmen dan hal tersebut dapat diadaptasikan menjadi rentang penerimaan atas berbagai pertimbangan yang didasarkan oleh keterlibatan ego.

\section{Penilaian Terhadap Karakteristik Brand Ambassador Tersampaikan}

Menurut informan Dhio Alghifari, Puradian Wiryadigda, Yana Adnanir dan Emilia Zahra bahwa pesan dalam iklan Stray Kids Shopee mudah tersampaikan, karena menurut mereka Stray Kids yang berasal dari Korea dapat berbahasa Indonesia dengan lumayan fasih, seperti diketahui penggunaan bahasa Indonesia dan pantun gombalan dalam iklan mereka sebagai bentuk promosi Shopee, sehingga menurut keempat informan penyampaian pesan mereka sangat bagus dan mudah tersampaikan. Hal serupa juga diutrakan oleh La Ode Abu Bakar dan Diva Yoti Agustian bahwa Stray Kids mudah memberi pesan tersampaikan, hal tersebut dikarenakan fans Kpop di Indonesia sangat banyak, terkhusus kaum wanita dan hal ini terbukti dengan pendapat informan yang bernama Diva Yoti Agustian bahwa iklan yang dibintangi Stray Kids tersebut membuat 
Jurnal Ilmu Komunikasi UHO : Jurnal Penelitian Kajian IImu Komunikasi dan Informasi.

Volume 6, No. 4, Oktober 2021, hlm 501-515

dirinya menjadi ingin lebih tau dan merasa aura semangat dalam iklan Stray Kids. Berbeda halnya dengan pendapat yang disampaikan oleh informan Ahmad Zulfadli menurutnya faktor pengalaman yang dimiliki Stray Kids membintangi berbagai iklan menjadi kunci kemampuan Stray Kids dalam menyampaikan pesan, hal ini dikarekan Stray Kids pernah membintangi berbagai brand seperti, Jambangee Jeans, Minute Maid Sparking, CGV, dan Pro-Specs.

Untuk melihat lebih dalam bagaimana pesan tersebut mudah tersampaikan, peneliti menanyakan mengenai keberhasilan pesan promosi dalam iklan Stray Kids, dari ketujuh informan bahwa mereka berpendapat hal yang sama yaitu penggunaan bahasa Indonesia yang disertai pantun gombalan menjadi kunci keberhasilan pesan iklan tersebut, menurut mereka pantun yang dilontarkan personel Stray Kids sangatlah unik dan menjadi daya tarik tersendiri, selain itu menurut Ahmad Zulfadli bahwa pantun tersebut menjadi konsep inovasi baru dalam periklanan.

Terdapat beberapa faktor yang menjadi kunci tersampainya pesan kepada penonton yakni, penempatan atau positioning dan konsep yang unik menjadi inovasi baru dan menghasilkan persepsi penonton menjadi positif, sehingga dalam konteks karakteristik brand ambassador tersampaikan masuk kedalam rentang penerimaan atau berada pada efek assimilation yang didasari oleh keterlibatan ego.

\section{Daya Tarik Fisik}

Daya tarik fisik yang dimiliki Stray Kids menunjukkan hasil yang positif, hal ini diperkuat dari hasil wawancara ketujuh informan yang serupa, mereka berpendapat bahwa Stray Kids yang berasal dari Korea memiliki daya tarik fisik berupa ketampanan, postur tubuh, dan fashion yang sangat bagus. Menurut informan bernama Puradian Wiryadigda bahwa Stray Kids mewakili Kpop dari Korea yang identik dengan fashion, model rambut, serta ketampanan mereka. Hal yang tidak jauh berbeda menurut ketiga informan lainnya, menurut La Ode Abu Bakar dan Dhio Alghifary bahwa daya tarik fisik yang dimiliki Stray Kids lebih mengarah kepada fans-fans Kpop yang kebanyakan berasal dari kalangan wanita, menurut mereka fisik yang dimiliki Stray Kids menarik karena ketampanan dan fashion mereka. hal ini memiliki kaitanya dengan pendapat menurut Lea-Greenwood (2013: 78) bahwa daya tarik yang harus dimiliki brand ambassador yaitu fisik seperti, gaya rambut, ketampanan dan fashion. Dari 
Jurnal Ilmu Komunikasi UHO : Jurnal Penelitian Kajian Ilmu Komunikasi dan Informasi.

Volume 6, No. 4, Oktober 2021, hlm 501-515

penilaian keenam informan bahwa persepsi mereka berada pada rentang penerimaan atau efek assimilation.

Berbeda halnya dengan pendapat informan Ahmad Zufadli yang menilai Stray Kids memiliki daya tarik fisik kepada wanita, tetapi menurutnya sebagai orang yang tidak menyukai Kpop menilai bahwa Shopee dan Stray Kids kurang sesuai menjadi brand ambassador Shopee, menurutnya Stray Kids lebih sesuai 'cocok' menjadi pengisi acara yang memeriahkan ulang tahun shopee. Seperti diketahui bahwa event 12.12 mempunyai makna tanggal 12 bulan 12 yang bertepatan tangal ulang tahun Shopee. Hal ini menunjukkan bahwa persepsi atau penilaian informan Ahmad Zulfadli berada pada rentang tidak komitmen atau netral, karena dalam hasil wawancara penggunaan kata "kurang pas" memiliki makna yang berada pada rentang netral, hal ini diperkuat dengan pendapatnya mengenai daya tarik fisik yang menarik untuk kuaum wanita. Sehingga penilaian ini dapat diposisikan dan berada pada rentang tidak komitmen (netral) dan dapat berada pada rentang penerimaan.

\section{Daya Tarik Non-Fisik}

Daya tarik non fisik yang dimiliki Stray Kids memberikan berbagai tanggapan dari ketujuh informan, menurut informan Puradian Wiryadigda dan Diva Yoti Agustian lebih kepada suara dan tampilan visual mereka, pengucapan bahasa indonesia yang lumayan fasih, gerakan dance dan suara personel yang bagus, sehingga menurut mereka Stray Kids memiliki daya tarik non fisik yang menarik. Hal serupa juga diungkapkan oleh kedua informan lainnya, menurut La Ode Abu Bakar Ramli dan Yana Adnanir bahwa stray kids memiliki basic (dasar) atau latar belakang dari Korea yang menjadi daya tarik tersendiri, La Ode Abu Bakar Ramli menambahkan pendapatnya bahwa Stray Kids memiliki nama atau kepoplueran yang mempengaruhi kesuksesan mereka dalam iklan shopee tersebut. Tidak hanya itu, menurut ketiga informan lainnya Dhio Alghifary, Ahmad Zulfadli dan Emilia Zahra bahwa daya tarik fisik mereka terletak pada pengalaman yang dimiliki stray kids, hal ini sesuai dengan pengalaman Stray Kids yang menjadi brand ambassador berbagai brand. Emilia Zahra juga menambahkan pendapatnya bahwa personel Stray Kids sudah sukses diusia yang muda dan dapat menjadi motivasi untuk kaum milenial di Indonesia. 
Jurnal Ilmu Komunikasi UHO : Jurnal Penelitian Kajian IImu Komunikasi dan Informasi.

Volume 6, No. 4, Oktober 2021, hIm 501-515

\section{Kesesuaian}

Karakteristik brand ambassador yang terakhir yaitu kesesuaian karakter, menurut keempat informan yang bernama Puradian Wiryadigda, Yana Adnanir, Dhio Alghifary dan La Ode Abu Bakar Ramli bahwa kesesuaian karakter antara shopee dan Stray Kids terletak pada penjualan berbagai produk atau barang-barang, mereka menilai bahwa aksesoris, style, fashion Stray Kids memiliki hubungan dengan Shopee karena penjualan berbagai produk. Pendapat yang serupa diungkapkan oleh informan Emilia Zahra dan Diva Yoti Agustian bahwa kesesuaian karakter Shopee yang mengarah kepada perkembangan zaman, menurut mereka yang sedang trend saat ini adalah Kpop, iklan berbagai kompetitor lainnya juga menggunakan brand ambassador berasal dari Korea. Dari keenam penilaian informan bahwa mereka berada pada rentang penerimaan, hal tersebut diperkuat karena mereka memiliki pengetahuan dan pengalaman terkait kesesuaian karakter Shopee dan Stray Kids.

Berbeda halnya dengan pendapat informan bernama Ahmad Zulfadli bahwa kesesuaian Shopee dengan Stray Kids kurang cocok "sesuai" karena menurutnya Stray Kids memiliki passion (bidang) pada dancer dan penyanyi sedangkan Shopee merupakan E-Commerce yang menjual berbagai produk, Ahmad Zulfadli juga berpendapat bahwa Shopee cocoknya menggunakan brand ambassador yang lebih mendunia dan dikenal berbagai kalangan. Jika dilihat dari penilaian Ahmad Zulfadli yang mengungkapkan dengan menggunakan kata "kurang cocok (sesuai)" maka penilaiannya berada pada rentang tidak komitmen, hal ini diperkuat karena penggunaan kata tersebut berada pada posisi netral dan dapat berubah menjadi penerimaan, karena pendapat sebelumnya bahwa menurutnya brand ambassador Stray Kids lumayan sukses jika dilihat dari jumlah tayangan melalui Youtube.

\section{SIMPULAN}

Persepsi Komunitas shopee tanam pada brand ambassador Stray Kids menunjukkan hasil yang positif, dari hasil wawancara ketujuh informan enam diantaranya berada pada rentang penerimaan (efek assimilation) karena mereka menilai kehadiran Stray Kids sebagai brand ambassador Shopee memberikan aura yang positif kepada penonton, keenam informan menilai bahwa Stray Kids sangat bagus dan sukses menjadi brand ambassador Shopee, hal ini didasari oleh beberapa faktor diantaranya, trend kpop di Indonesia, kepopuleran stray kids, daya tarik ISSN: 2527-9173. Website: http://ojs.uho.ac.id/index.php/KOMUNIKASI/index 
Jurnal IImu Komunikasi UHO : Jurnal Penelitian Kajian Ilmu Komunikasi dan Informasi.

Volume 6, No. 4, Oktober 2021, hlm 501-515

fisik dan non fisik (fashion, ketampanan, postur tubuh, tampilan dance, suara, latar belakang dan pengalaman Stray Kids) dan kesesuaian karakter Shopee dengan Stray Kids, kesesuaian yang dimaksud adalah Shopee menjual segala produk, termasuk aksesoris, pakaian fashion dan segala hal mengenai Korea. Sehingga mengakibatkan adanya kesesuaian. Sedangkan satu informan menunjukkan hasil yang berada pada rentang tidak komitmen (latitude of noncommitment), hal tersebut dikarenakan beberapa pertimbangan yang mempengaruhi persepsinya, tetapi hal tersebut dapat diadaptasikan menjadi positif. Hal ini menunjukan bahwa kehadiran brand ambassador shopee yang dibintangi Stray Kids berbeda karena tidak mengalami respon negatif atau efek contrast (rentang penolakan) yang terjadi pada brand ambassador BlackPink dan Ronaldo. Hal ini diperkuat dengan adanya keterlibatan ego yang didasarkan oleh pengalaman serta pengetahuan informan terkait brand ambassador Stray Kids. Dari hasil penelitian ini menunjukan bahwa populer culture memiliki peran penting dalam penggunaan brand ambassador. 
Jurnal IImu Komunikasi UHO : Jurnal Penelitian Kajian IImu Komunikasi dan Informasi.

Volume 6, No. 4, Oktober 2021, hlm 501-515

\section{DAFTAR PUSTAKA}

Kotler, P., \& Keller, K. L. (2009). Manajemen Pemasaran, Edisi 13. Jakarta: Erlangga, 14.

Lea-Greenwood, G. (2013). Fashion marketing communications. John Wiley \& Sons.

Morissan. 2013. Teori komunikasi : individu hingga massa, Jakarta Kendana.

\section{Laporan Penelitian/Skripsi}

Prawira, Y., Murniati, D., Rusli, A., Giriputro, S., Setiawaty, V., Oswari, H., \& Said, M. (2012). Clinical, laboratory, and radiologic characteristics of confirmed avian influenza (H5N1). Southeast Asian J Trop Med Public Health, 43(4), 877-889.

Ummah, L. D. (2018). Rancang Bangun E-Commerce Pada Toko Kerudung Nuri Collection Berbasis Customer Relationship Management. Nuansa Infor

\section{Internet}

Indosiar. 2019. Shopee Indoensia Gaet CR7 jadi Brand Ambassador Internasioal Terbaru. Melalui https://youtu.be/yiAXbU0MQb8 [Diakses Pada Tanggal 26 Februari 2021Wita]

Herawati. 2018. Hentikan Iklan Blackpink Shopee. Melalui https://www.change.org/p/komisi-penyiaran-indonesia-hentikan-iklan-blackpinkshopee/w?source_location=petition_nav [Diakses Pada Tanggal 28 Februari 2021 Pukul 01.02 Wita]

Kumparan. 2018. Reaksi Netizen Soal Iklan Blackpink Yang Dihentikan KPI. Melalui https://kumparan.com/kumparank-pop/reaksi-netizen-soal-iklan-blackpinkyang-dihentikan-kpi-1544529188190357011/full [Diakses Pada Tanggal 3 Agustus 2020 Pukul 20.20 Wita]

Kumparan. 2019. Deretan Iklan yang Pernah Dibintangi Stray Kids. Melalui https://kumparan.com/kumparank-pop/deretan-iklan-yang-pernah-dibintangistray-kids-1548058651036320676 [Diakses Pada Tanggal 3 Mei 2021 Pukul 20.20 Wita]

Reza. 2019. Iklan 'Receh' Shopee bersama CR7 Mendadak Viral di Dunia" Melalui https://www.bola.com/dunia/read/4042829/iklan-receh-shopee-bersama-cr7mendadak-viral-di-dunia [Diakses Pada Tanggal 3 Agustus 2020 Pukul 20.22 Wita] 
Jurnal Ilmu Komunikasi UHO : Jurnal Penelitian Kajian Ilmu Komunikasi dan Informasi.

Volume 6, No. 4, Oktober 2021, hlm 501-515

Shopee. 2021. Shopee Tanam Kilat. Melalui https://shopee.co.id/m/shopee-tanam-kilat [Diakses Pada Tanggal 1 Juli 2021 Pukul 19.40 Wita]

Survey Hootsuite. 2021. Indonesian Digital Report. Melalui https://www.hootsuite.com/id/research/social-trends [Diakses Pada Tanggal 22 Februari 2021 Pukul 19.40 Wita]

Survey Iprice. 2021. Peta E-Commerce Indonesia. Melalui https://iprice.co.id/insights/mapofecommerce/ [Diakses Pada Tanggal 22 Februari 2021 Pukul 19.20 Wita]

Survey Snapchart. 2020 Duniafintech Shopee Jadi Pilihan Belanja Online 2020. Melalui https://duniafintech.com/shopee-jadi-pilihan-belanja-online-di-tahun-2020/ [Diakses Pada Tanggal 28 Februari 2021 Pukul 23.26 Wita]

Whatsapp. 2021. Komunitas Online Shopee Tanam. Melalui https://chat.whatsapp.com/CXxpQmWtlQQBCEJbCd8r1I [Diakses Pada Tanggal 22 Maret 2021 Pukul 18.29 Wita] 